\title{
A METHOD FOR DETECTING AND TYPING OF SALMONELLA BY MULTIPLEX PCR
}

\author{
Borys Stegniy ${ }^{1}$, Anton Gerilovych ${ }^{2}$, Vasiliy Arefyev ${ }^{2}$, \\ Katerina Glebova ${ }^{1}$, Aleksandar Potkonjak ${ }^{3}$ \\ ${ }^{1}$ Laboratory for Study of Avian Viral Diseases, NSC IECVM, Kharkiv 61023, Ukraine \\ ${ }^{2}$ Laboratory of Molecular Epizootology and Diagnostics, \\ NSC IECVM, Kharkiv 61023, Ukraine \\ ${ }^{3}$ University of Novi Sad, Faculty of Agriculture, Department \\ of Veterinary Medicine, Novi Sad, Serbia.
}

\section{Abstract}

Today in Ukraine's market is increasing the volume of trade with livestock products. Also the number of catering services and grocery shops selling ready-made food is growing throughout the country. The veterinary service should have time to check the quality of all of these products. Only traditional bacteriological methods of isolation and identification of pathogens of toxicoinfection, which is not enough in terms of increasing turnover of products, are used today. The one of the most dangerous toxicoinfections is salmonellosis. Typing different Salmonella species gives an answer about the source of infection. The aim of our work was to develop a system of identification of Salmonella and typing among them five serovars based on the polymerase chain reaction (multiplex PCR). We performed analysis of the nucleotide sequences of the five members of the genus Salmonella, on the basis of which a primer designed for the identification of any member of the genus Salmonella with simultaneous typing - Salmonella enterica ser. Enteritidis, Salmonella enterica ser. Typhimurium, Salmonella enterica ser. Typhi, Salmonella enterica ser. Dublin, Salmonella enterica ser. GallinarumPullorum by multiplex PCR. The protocol of multiplex PCR was optimization with simples positive DNA matrix.

Key words: salmonella, multiplex PCR, typing DNA. 


\title{
MULTIPLEX PCR METOD ZA DETEKCIJU I TIPIZACIJU SALMONELA
}

\author{
Borys Stegniy ${ }^{1^{*}}$, Anton Gerilovych ${ }^{2}$, Vasiliy Arefyev ${ }^{2}$, \\ Katerina Glebova ${ }^{1}$, Aleksandar Potkonjak ${ }^{3}$ \\ ${ }^{1}$ Laboratorija za izučavanje virusnih bolesti ptica, Nacionalni naučni centar \\ "Institut za eksperimentalnu i kliničku veterinarsku medicinu", Harkov, Ukrajina \\ ${ }^{2}$ Laboratorija za molekularnu epizootiologiju i dijagnostiku, Nacionalni naučni centar \\ "Institut za eksperimentalnu i kliničku veterinarsku medicinu”, Harkov, Ukrajina \\ ${ }^{3}$ Univerzitet u Novom Sadu, Poljoprivredni fakultet, Departman \\ za veterinarsku medicinu, Novi Sad, Srbija.
}

\section{Kratak sadržaj}

Danas na ukrajinskom tržištu postoji povećanje obima trgovine animalnim proizvodima. Takođe, broj ketering agencija i trgovina mešovite robe koje prodaju gotovu hranu raste u celoj zemlji. Veterinarskoj službi treba dosta vremena za proveru kvaliteta svih tih proizvoda, jer danas na raspolaganju imamo samo tradicionalne bakteriološke metode izolacije i identifikacije uzročnika toksoinfekcija, što nije dovoljno s obzirom na sve veći promet proizvoda. Jedna od najopasnijih toksoinfekcija je salmoneloza. Tipizacija različitih Salmonella vrsta daje odgovor o izvoru zaraze. Cilj našeg rada bio je razvijenanje sistema zasnovanog na lančanoj reakciji polimeraze za identifikaciju bakterija iz roda Salmonella i tipizaciju pet serotipova (multiplex PCR). Izvršili smo analizu nukleotidnih sekvenci za pet članova roda Salmonella i dizajniranje prajmera za identifikaciju bilo kog člana roda Salmonella sa istovremenom tipizacijom - Salmonella enterica ser. Enteritidis, Salmonella enterica ser. Typhimurium, Salmonella enterica ser. Typhi, Salmonella enterica ser. Dublin, Salmonella enterica ser. Gallinarum-Pullorum metodom multiplex PCR. Optimizacija protokola metode multiplex PCR je izvršena sa jednostavnim pozitivnim matricama DNK.

Ključne reči: Salmonella, multiplex PCR, DNK tipizacija

\section{INTRODUCTION}

Salmonellosis - one of the most dangerous diseases that is caused by serotypes of bacteria of the genus Salmonella, which have mechanisms for habitat and parasitism in the gastrointestinal tract (Althouse et al., 2003; Chiu et al., 2010).

$1^{*}$ Vasiliy Arefev, Pushkinska 83, Kharkiv 61023, Ukraine, Phone: +38(057)707-20-31, E-mail: vasilii.arefev@gmail.com 
According to the current classification, S. enterica is divided into six subspecies: Salmonella enterica subspecies enterica, Salmonella enterica subspecies salamae, Salmonella enterica subspecies arizonae, Salmonella enterica subspecies diarizonae, Salmonella enterica subspecies houtenae and Salmonella enterica subspecies indica, which differentiate by the biochemical activity and represent the number of subtypes I, II, IIIa, IIIb, IV , and VI , respectively. Salmonella enterica subspecies enterica is mostly isolated in the majority of cases of Salmonella infection from animal and human (Althouse et al., 2003; Battistuzzi et al., 2004).

Salmonella contamination occurs through the consumption of contaminated food: eggs and egg products, milk and dairy products, meat birds and other animals. Another way of infection is the transfer of infections through tap water, in addition, the sources of infection can be the open water (Bailey, 1998). According to the FAO, $20 \%$ of poultry products in the world are contaminated with Salmonella, and they can persist for a long time in the animal facilities because they can form a surface film (Vestby et al., 2009; http://www. fao.org/docrep/012/i1133e/i1133e00.htm). Annually on the planet are registered 21 million cases of typhoid fever, and about 216 thousand cases (Zhou and Pollard, 2010).

Worldwide, the monitoring of the incidence of salmonellosis in which tracked various options for its manifestation. As well as a comparison of Salmonella strains isolated from humans and animals (Chiu et al., 2009; Chiu et al, 2010; Laupland et al, 2010).

The system of quality control of food, raw materials, based on the use of bacteriological methods of investigation (D’Aoustlnt, 1991).

As an alternative to traditional bacteriological methods for the identification and typing of Salmonella proposes the use of polymerase chain reaction (dos Santos, 2001; Zahraei Salehi et al., 2005; Eyigör et al, 2007; Cao et al., 2008; Mirmomeni et al., 2008; Zhou et al., 2010).

Analysis of antigen alleles H1 (i, g, m, r or z10) allowed fast typed serological variants enteritidis, hadar, heidelberg and typhimurium (Hong et al., 2008).

To date, Ukraine has not yet widespread methods of rapid diagnosis of salmonellosis. Typing of the pathogen is an essential component of diagnosis, because it can give an answer about the alleged source of infection. For this reason, the aim of our work was the development of the national test system based on the polymerase chain reaction, which would like to identify and typed some key members of the genus Salmonella (Gerylovich, 2011). 


\section{METHODS AND MATERIALS}

The objects of our study were Salmonella spp., Salmonella enterica ser. Enteritidis, Salmonella enterica ser. Typhimurium, Salmonella enterica ser. Typhi, Salmonella enterica ser. Dublin, Salmonella enterica ser. Gallinarum-Pullorum. For the construction of genus-and species-specific primers electronic databases of sequences of essential genes in Salmonella contained in the international database GenBank (http://www.ncbi.nlm.nih.gov/genbank/) were analyzed.

Multiple alignment of selected sequences, and their subsequent analysis to select PCR primers was performed using the computer program Bio Edit (v.7.2.4).

The protocol of polymerase chain reaction has been developed on the basis of the primer systems with a certain temperature, the selection of components for the formulation of the multiplex PCR and the identification of the genus Salmonella spp. and typing of the five listed above serotypes (Elnifro, 2000; Kaderali, 2007).

One-day-old cultures of Salmonella from the museum sector study mycoplasmoses and salmonellosis are grown for meat - peptone medium were used as the source of positive DNA-matrix.

Extraction of total nucleic acid was carried out using micro columns. To $450 \mu \mathrm{l}$ of Extraction buffer was added $100 \mu \mathrm{l}$ of Salmonella culture. After lysis of the containments from the tubes were transferred to microcolumns and centrifuged. This was followed by washing with ethanol followed by extraction of total nucleic acid of TE-buffer.

DNA concentration was calculated by spectrophotometery at $260 \mathrm{~nm}$.

\section{RESULTS AND DISCUSSIONS}

The nucleotide sequences of the major genes were analyzed. The greatest breadth of sample homogeneity and sequenced portions of the gene was detected in invA for all members of the genus Salmonella. In the computer analysis of the gene sequences invA was selected 22 pairs of oligonucleotides - potential pairs of primers for PCR. The PCR product limited by size of $387 \mathrm{bp}$ in length, and olygonucleotides were called Salm3_4.

For Salmonella enterica ser. Enteritidis specific motifs were found in the gene SefA. Sequence analysis of this gene allowed to establish the potential 6 primer pairs. The primers flanking portion length $299 \mathrm{bp}$ were selected.

The gene fliC demonstrated specificity for Salmonella enterica ser. Typhimurium. The primers flanking region $420 \mathrm{bp}$ were choosed. 
Gene viaB contained specific motives for Salmonella enterica ser. Typhi. Accordingly, on this basis was chosen area, which limited the targeted gene fragment length $738 \mathrm{bp}$.

For the genome of Salmonella enterica ser. Dublin serospecific motifs were found in SeD_A1104 gene. When bioinformatics studies were identified primers flanking the product of $203 \mathrm{bp}$.

Finally, gene SG0266 was elected by containing specific motifs for Salmonella enterica ser. Gallinarum-Pullorum. Specific primers flanking length of 97 bp region were selected in analyzed area.

Table 1. Nucleotide sequence and PCR product.

\begin{tabular}{|c|c|c|c|}
\hline Salmonella & Primer & $5^{\star}-3^{*}$ & $\begin{array}{c}\text { PCR } \\
\text { product, } \\
\text { bp. }\end{array}$ \\
\hline \multirow{2}{*}{ Salmonella spp. } & Salm 3 & GCTGCGCGCGAACGGCGAAG & \multirow{2}{*}{387} \\
\hline & Salm4 & TCCCGCCAGAGTTCCCATT & \\
\hline \multirow{2}{*}{$\begin{array}{l}\text { Salmonella } \\
\text { enterica ser. } \\
\text { Enteritidis }\end{array}$} & Sent F & AAATGTGTTTTATCTGATGCAAGAGG & \multirow{2}{*}{299} \\
\hline & Sent R & GTTCGTTCTTCTGGTACTTACGATGAC & \\
\hline \multirow{2}{*}{$\begin{array}{l}\text { Salmonella } \\
\text { enterica ser. } \\
\text { Typhimurium }\end{array}$} & Styp F & CCCCGCTTACAGGTCGACTAC & \multirow{2}{*}{433} \\
\hline & Styp R & AGCGGGTTTTCGGTGGTTGT & \\
\hline \multirow{2}{*}{$\begin{array}{l}\text { Salmonella ente- } \\
\text { rica ser. Typhi }\end{array}$} & Styphi_F & CACGCACCATCATTTCACCG & \multirow{2}{*}{738} \\
\hline & Styphi_R & AACAGGCTGTAGCGATTTAGG & \\
\hline \multirow{2}{*}{$\begin{array}{l}\text { Salmonella ente- } \\
\text { rica ser. Dublin }\end{array}$} & Sdub_F & ACGCGAAATCTGATGGTCTT & \multirow{2}{*}{203} \\
\hline & Sdub_R & GCCCACCAGTTGTGAAAGGC & \\
\hline \multirow{2}{*}{$\begin{array}{l}\text { Salmonella ente- } \\
\text { rica ser. Gallina- } \\
\text { rum-Pullorum }\end{array}$} & Sgal_F & CCGCACAACACATCAGAAAG & \multirow{2}{*}{97} \\
\hline & Sgal_R & AGCTGCCAGAGGTTACGCTG & \\
\hline
\end{tabular}


After synthesis of primers, we performed optimization of the PCR protocol. As the positive control for PCR we used DNA extracted from the oneday-old culture of Salmonella which have been stored in the museum NSC " IECVM “.

The obtained DNA matrix concentration after measuring with a spectrophotometer, we have led to the same concentration and then put PCR.

The first stage was carried out testing each primer pair using the standard composition of the reaction mixture at different temperatures.

To determine optimal temperature parameters PCR was performed with various primer annealing temperature: $58^{\circ} \mathrm{C}, 60^{\circ} \mathrm{C}, 63^{\circ} \mathrm{C}$ and $65^{\circ} \mathrm{C}$. As a result, established the following optimal amplification:

- Initial denaturation - $94^{\circ} \mathrm{C}-2 \mathrm{~min}$;

- Denaturation- $94^{\circ} \mathrm{C}-30 \mathrm{~s}$;

$\left.\begin{array}{l}\text { Annealing }-63^{\circ} \mathrm{C}-30 \mathrm{~s} ; \\ \text { - }\end{array}\right\} 40$ cycles

- Final extension $-72^{\circ} \mathrm{C}-5 \mathrm{~min}$

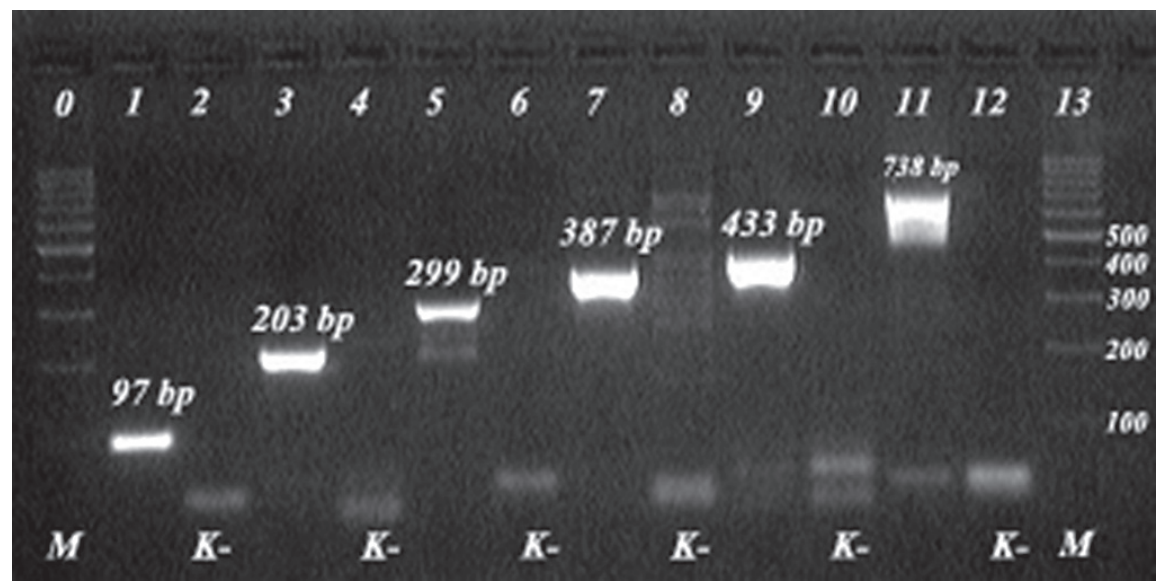

Figure 1. Electropherogram of results of initial testing of primers with positive DNA template: Track number 1 - corresponds the Salmonella enterica ser. GallinarumPullorum aplicon (97 bp) lane number 3 - corresponds to the amplicon for Salmonella enterica ser. Dublin - (203 bp), lane number 5 - corresponds to the amplification Salmonella enterica ser. Enteritidis - (299 bp), lane number 7 - corresponds to the amplicon for Salmonella spp. - (387 bp), track number 9 - corresponds to the amplicon for Salmonella enterica ser. Typhimurium - (433 bp), track number 11 - corresponds to the amplicon for Salmonella enterica ser. Typhi - (738 bp.) 
To set up the multiplex PCR, the optimization of reaction was performed using the basic sets for the amplification produced by Thermo Scientific (Lithuania).

Table 2. The composition of the reaction mixture for multiplex PCR

\begin{tabular}{|c|l|c|}
\hline$№$ & Components & \\
\hline 1 & 10×DreamTaq Buffer & $2,5 \mu \mathrm{l}$ \\
\hline 2 & dNTP Mix, 2 mM each & $2,5 \mu \mathrm{l}$ \\
\hline 3 & 25 mM MgCl2 & $0,5 \mu \mathrm{l}$ \\
\hline 4 & Primer Styphi_Forward, (conc. $40 \mathrm{pM}$ ) & $40,0 \mathrm{pM}$ \\
\hline 5 & Primer Styphi_Reverse, (conc. $40 \mathrm{pM}$ ) & $40,0 \mathrm{pM}$ \\
\hline 6 & Primer Styp_Forward, (conc. $40 \mathrm{pM}$ ) & $20,0 \mathrm{pM}$ \\
\hline 7 & Primer Styp_Reverse, (conc. $40 \mathrm{pM})$ & $20,0 \mathrm{pM}$ \\
\hline 8 & Primer Salm_3 Forward, (conc. $40 \mathrm{pM})$ & $20,0 \mathrm{pM}$ \\
\hline 9 & Primer Salm_4 Reverse, (conc. $40 \mathrm{pM})$ & $20,0 \mathrm{pM}$ \\
\hline 10 & Primer Sent_Forward, (conc. $40 \mathrm{pM})$ & $10,0 \mathrm{pM}$ \\
\hline 11 & Primer Sent_Reverse, (conc. $20 \mathrm{pM}$ ) & $10,0 \mathrm{pM}$ \\
\hline 12 & Primer Sdub_Forward, (conc. $20 \mathrm{pM}$ ) & $10,0 \mathrm{pM}$ \\
\hline 13 & Primer Sdub_Reverse, (conc. $20 \mathrm{pM}$ ) & $10,0 \mathrm{pM}$ \\
\hline 14 & Primer Sgal_Forward, (conc. $20 \mathrm{pM}$ ) & $10,0 \mathrm{pM}$ \\
\hline 15 & Primer Sgal_Reverse, (conc. $20 \mathrm{pM}$ ) & $10,0 \mathrm{pM}$ \\
\hline 16 & Template DNA & $10 \mathrm{pg}-$ \\
& & $1 \mu \mathrm{g}$ \\
\hline 17 & DremTaq DNA Polymerase & $10,0 \mathrm{U}$ \\
\hline 18 & Water, nuclease-free & to $25,0 \mu \mathrm{l}$ \\
\hline & & $25,0 \mu \mathrm{l}$ \\
\hline
\end{tabular}

We have increased the time of denaturation of DNA to 45s for multiplex PCR-protocol establishment. The annealing of primers was also prolonged to the $45 \mathrm{~s}$, elongation time was increased to 1 minute. Final elongation was 10 $\min$ : 
- Initial denaturation - $94^{\circ} \mathrm{C}-2 \mathrm{~min}$;

- Denaturation- $94^{\circ} \mathrm{C}-45 \mathrm{~s}$;

$\left.\begin{array}{l}\text { Annealing }-63^{\circ} \mathrm{C}-45 \mathrm{~s} ; \\ \text { - } \quad \text { Extension }-72^{\circ} \mathrm{C}-1 \mathrm{~min} ;\end{array}\right\} 40$ cycles

- Final extension $-72^{\circ} \mathrm{C}-10 \mathrm{~min}$

This mode is enabled to carry out the amplification of the expected fragments (Fig. 2) in a single reaction.

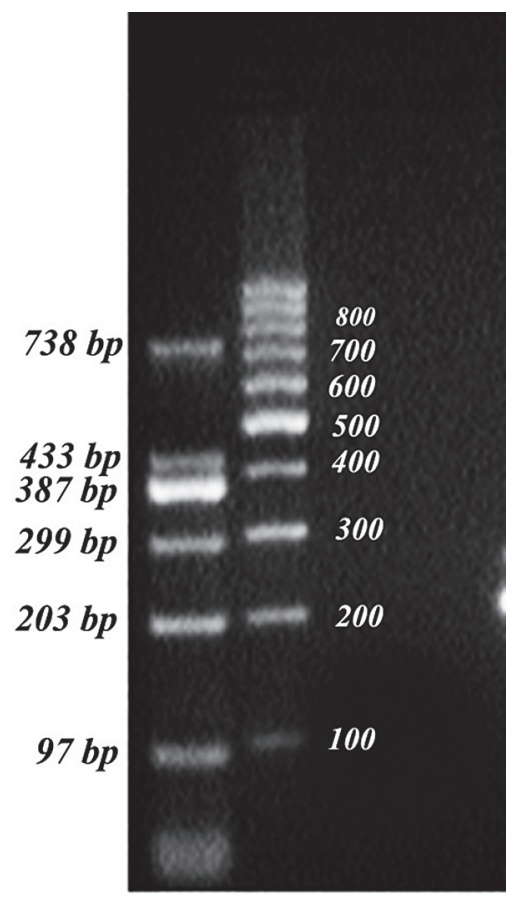

Figure 2. Electropherogram results Multiplex - PCR

\section{CONCLUSIONS}

The primer system, which allows simultaneous identification of a multiplex - PCR its five core members (Salmonella enterica ser. Enteritidis, Salmonella enterica ser. Typhimurium, Salmonella enterica ser. Typhi, Salmonella enterica ser. Dublin, Salmonella enterica ser. Gallinarum-Pullorum) has been developed. 
Multiplex PCR protocol could be applied in the laboratories for identification and typing of Salmonella in the shortest possible time. Also, the system can be convenient for monitoring Salmonella contamination of various objects, while typing their main representatives.

\section{ACKNOWLEDGE}

The authors thank senior researcher studying pathology of reproduction Bolotin Vitaly I., and Roxana Sanchez-Ingunza, DVM, PhD Research Microbiologist Egg Safety and Quality Research Unit USDA, ARS, RRC 950 College Station Road Athens, GA 30605 USA for assistance in the Science.

\section{LITERATURE}

1. Althouse C., Patterson S., Fedorka-Cray P. , Isaacson R.E.: Type 1 fimbriae of Salmonella entericaserovar Typhimurium bind to enterocytes and contribute to colonization of swine in vivo. Infection Immunity, 71, 6446-6452, 2003

2. Bailey, J.L.: Detection of Salmonella cells within 24 to 26 hours in poultry samples with the polymerase chain reaction BAX system. Journal of Food Protection, 61, 792-795, 1998

3. Battistuzzi F.U., Feijao A., Hedges S.B.: A genomic timescale of prokaryote evolution: insights into the origin of methanogenesis, phototrophy, and the colonization of land. BMC Evolutionary Biology, 4, 44, 2004

4. Chiu L.H., Chiu C.H., Horn Y.M. Shil S.K., Christensen J.P.: Characterization of 13 multi-drug resistant Salmonella serovars from different broiler chickens associated with those of human isolates. BMC Microbiology, 10, 86,2010

5. Chui K.K.H., Webb P., Russell R.M., Naumova E.N.: Geographic variations and temporal trends of Salmonella associated hospitalization in the U.S. elderly, 1991-2004: A time series analysis of the impact of HACCP regulation. BMC Public Health, 9, 447, 2009

6. D'Aoustlnt, J.Y. Pathogenicity of foodborne Salmonella. Journal of Food Microbiol, 12, 14-70, 1991

7. Elnifro E. M.: Multiplex PCR: optimization and application in diagnostic virology. Clinical Microbiology Reviews, 13, 4, 559-570, 2000

8. Eyigör A., Goncagül G., Tayfun C.K.: A PCR- ELISA for the detection of Salmonella from chicken intestine. Journal of Environmental Sciences, 1, 1, $45-49,2007$ 
9. FAQ feedstuff control annual report FAO newsletter -2010.- 282 p. http:// www.fao.org/docrep/012/i1133e/i1133e00.htm

10. Gerylovich A.P. Development of oligonucleotide systems for detection of Salmonella in biological subjects. In: Arefyev V.L., Vovk S.I. Veterinary medicine: Interdepartmental subject scientific collection, Kharkov, 95, 2011

11. Hong Y., Liu T., Lee M.D. Maier M., White D.G., Ayers S., Wang L., Berghaus R., Maurer J.J.: Rapid screening of Salmonella entericaserovars Enteritidis, Hadar, Heidelberg and Typhimurium using a serologically-correlative allelotyping PCR targeting the $\mathrm{O}$ and $\mathrm{H}$ antigen alleles. BMC Microbiology, $8,178,2008$

12. Kaderali, L.: Primer design for multiplexed genotyping. Methods in Molecular Biology, 402, 269-286, 2007

13. Laupland K.B., Schǿnheyder H.C., Kennedy K.J., Lyytikäinen O., Valiquette L., Galbraith J., Collignon P.: Salmonella entericabacteraemia: a multinational population-based cohort study. BMC Infectious Diseases, 10, 95, 2010

14. dos Santos L., do Nascimento V., de Oliveira S. D., Flores M. L., Pontes A., Ribeiro A.R., Salle C.T.P., Lopes R.F.F.: Polymerase chain reaction (PCR) for the detection of Salmonella in artificially inoculated chicken meat. Revista do Instituto de Medicina Tropical de São Paulo, 43, 5, 247 - 250, 2001

15. Mirmomeni M.H., Kiani S. and Sisakhtnezhad S.: Rapid detection of Salmonella Dublin by PCR amplification of the SopE Gene and its Cloning. Pakistan Journal of Biological Science, 11, 11, 1497 - 1501, 2008

16. Cao S.Y., Wang M.S., Cheng A.C., Qi X.F., Yang X.Y., Deng S.Y., Yin N.C., Zhang Z.H., Zhou D.H., Zhu D.K., Luo Q.H, Chen X.Y.: Comparative analysis of intestinal microbial community diversity between healthy and orally infected ducklings with Salmonella enteritidis by ERIC-PCR. World Journal of Gastroenterology, 21, 14, 7, 1120-1125, 2008

17. Vestby L.K., Møretrø T., Langsrud S., Heir E., Nesse L.L..: Biofilm forming abilities of Salmonella are correlated with persistence in fish meal- and feed factories. BMC Veterinary Research, 5, 20,2009

18. Zahraei Salehi T., Mahzounieh M., Saeedzadeh A.: Detection of InvA Gene in Isolated Salmonella from Broilers by PCR Method: International Journal of Poultry Science 4, 8, 557-559, 2005

19. Zhou L., Pollard A.J.: A fast and highly sensitive blood culture PCR method for clinical detection of Salmonella enterica serovar Typhi. Annals of Clinical Microbiology and Antimicrobials, 9, 14, 2010.

Primljeno: 15.10 .2014

Odobreno: 20.11.2014. 